\title{
Correction to: New phenylalkanoids from the rhizome of Cnidium officinalis Makino
}

Hyoung-Geun Kim', Trong Nguyen Nguyen', Yeong-Geun Lee ${ }^{1}$, Min-Ho Lee², Dae Young Lee³, Youn-Hyung Lee ${ }^{4^{*}}$ and Nam-In Baek ${ }^{\text {* }^{*}}$

\section{Correction to: Appl Biol Chem (2021) 64:79} https://doi.org/10.1186/s13765-021-00650-1

The original version [1] of the article unfortunately contained a mistake. The email address was repeated twice mistakenly in the affiliation section.

It has been corrected in this correction.

It should be

"Correspondence: nibaek@khu.ac.kr; younlee@khu.ac.kr

\section{Reference}

1. Kim HG, Nguyen TN, Lee YG, Lee MH, Lee DY, Lee YH, Baek NI (2021) New phenylalkanoids from the rhizome of Cnidium officinalis Makino. Appl Biol Chem 64:79. https://doi.org/10.1186/s13765-021-00650-1

\section{Publisher's Note}

Springer Nature remains neutral with regard to jurisdictional claims in published maps and institutional affiliations.

\section{Author details}

${ }^{1}$ Graduate School of Biotechnology and Department of Oriental Medicinal Biotechnology, Kyung Hee University, Yongin 17104, Republic of Korea. ${ }^{2}$ Department of Food Technology and Services, Eulji University, Seongnam 461-723, Republic of Korea. ${ }^{3}$ Department of Herbal Crop Research, National Institute of Horticultural and Herbal Science, RDA, Eumseong 27709, Republic of Korea. ${ }^{4}$ Department of Horticultureal Biotechnology, Kyung Hee University, Yongin 17104, Republic of Korea.

Published online: 07 January 2022

The original article can be found online at https://doi.org/10.1186/s13765021-00650-

*Correspondence: nibaek@khu.ac.kr; younlee@khu.ac.kr

${ }^{1}$ Graduate School of Biotechnology and Department of Oriental

Medicinal Biotechnology, Kyung Hee University, Yongin 17104, Republic

of Korea

${ }^{4}$ Department of Horticultureal Biotechnology, Kyung Hee University,

Yongin 17104, Republic of Korea

Full list of author information is available at the end of the article

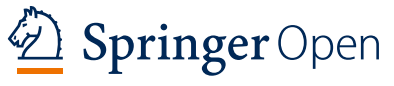

(c) The Author(s) 2022. Open Access This article is licensed under a Creative Commons Attribution 4.0 International License, which permits use, sharing, adaptation, distribution and reproduction in any medium or format, as long as you give appropriate credit to the original author(s) and the source, provide a link to the Creative Commons licence, and indicate if changes were made. The images or other third party material in this article are included in the article's Creative Commons licence, unless indicated otherwise in a credit line to the material. If material is not included in the article's Creative Commons licence and your intended use is not permitted by statutory regulation or exceeds the permitted use, you will need to obtain permission directly from the copyright holder. To view a copy of this licence, visit http://creativecommons.org/licenses/by/4.0/. 